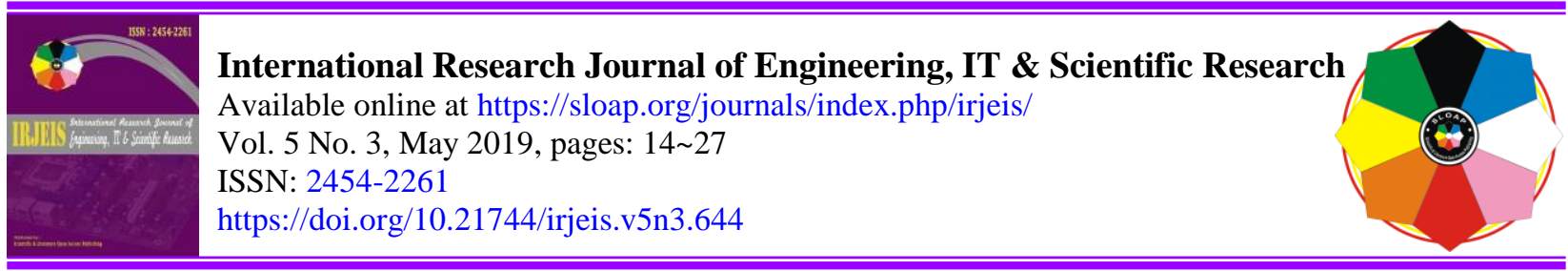

\title{
Impact of MGNREGS on Dalit Women: A Case Study of Nagari Mandal in Chittoor District
}

Article history:

Received: 9 December 2018

Accepted: 31 March 2019

Published: 31 May 2019

\section{Keywords:}

dalit women; discrimination;

employment;

generation;

inflation;

\begin{abstract}
The study found that Dalit women are facing discrimination in the payment of wages. They are not equally paid to both men and women. Hence, it is suggested that the government should take necessary steps to equal wages to both men and women. The study found that income generation under the MGNREGS was meager. This is due to the low wage rate. Hence, it is suggested that the wage rate should be a hike from Rs.121 to Rs.200 per day as the inflation rate has gone up. Also suggested to link this with market wage rate and make changes accordingly. It is found that most of the Dalit women faced problems in getting employment under the MGNREGS. There are problems at the time of applying for job cards, at the time of issuing job cards, problems in informing about employment, problems in the payment of wages, political involvement, etc. Hence, it is suggested that online facility should be arranged to apply an issue of job cards.
\end{abstract}

2454-2261 ${ }^{\circledR}$ Copyright 2019. The Author. This is an open-access article under the CC BY-SA license (https://creativecommons.org/licenses/by-sa/4.0/) All rights reserved.

\section{Author correspondence: \\ T. Narasimhulu, \\ Lecturer in Economics, Government Degree College \\ NAGARI-517590, CHITTOOR Dist., A.P. \\ Email address: narasimha.tirivilli90@gmail.com}

\section{Introduction}

Rural development is the main pillar of the nation's development. The reasons for this are obvious. In spite of rapid urbanization, a large section of our population still lives in the villages. Secondly, rural India has lagged behind in development because of many historical factors. Development as a concept, when applied in the specific context of rural India, acquires a new meaning as rural development. Fundamentally, development of rural area means not only the aggregate development of the area but also the development of the people living in rural areas. The objectives of rural development are multi-directional as well as multi-dimensional. It aims at increased employment, higher productivity, higher income as well as acceptable levels of food, clothing, shelter, education, health and building up of a sound value system which is in keeping with the high cultural heritage of the country. Thus, rural development means all aspects of human development.

${ }^{a}$ Lecturer in Economics, Government Degree College Nagari-517590, Chittoor Dist., India 
Rural development is necessary not only because of an overwhelming majority of the population lives in villages but also because the development of rural activities is essential to accelerate the pace of overall economic development of the country. India is land of villages and her economy continues even today to be mainly rural. A village is also an important unit in the organization of Indian social life. The village community should exercise by the greatest influence upon the social, economics, and political life of the country. At present, there are about $5,93,615$ villages in India. The village is a cluster of mud houses and thatched huts, narrow, uneven and winding streets running between rows of houses, thatched or roofed with tiles made perhaps by the local potter. Moreover, a low standard of living, an inadequate and unbalanced diet, meager and rough clothing, unsanitary housing, etc., are the characteristic features of an Indian village.

According to 2011 census there are 833.4 million in rural areas. The ratio of the rural population has decreased from $89.2 \%$ to $72.1 \%$ during the century. At the same time, the urban population was increased from $10.8 \%$ to $28.8 \%$. The problems of rural areas in India are the outcome of physical, economic and cultural aspects of the region. They are physical problems, economic problems, and cultural problems. The economic problems of the country are lack of building materials, particularly for the poor, no arrangement for septic tanks either for a family or for the whole community lack of roads, railways and other means of communication, lack of rural credit guidance for house improvement, lack of marketing facilities (Kustina at al., 2018; Pandey, 2017; Vishwakarma, 2016).

From the above analysis, rural India is facing many problems like irrigation, roads, infrastructure, electricity, etc. All these problems affect adversely on the Indian economy. Mainly these are the causes of poverty, unemployment, etc. To eradicate these problems the Centre and the State Governments are implementing different programs for rural development. The following analysis concentrates on various rural development programs.

Most Dalits continue to live in extreme poverty, without land or opportunities for better employment or education with the exception of a minority who have benefited from India's policy of quotas in education and Government jobs. Dalits are relegated to the most memorable of tasks as manual scavengers, removers of human-based and dead animals, leather workers, streets sweepers, and cobbler. Dalit children make up the majority of those sold into bondage to pay off debts to upper caste creditors. Dalit men, Women, and children numbering in the tens of millions working as agricultural laborers for a few kilograms of rising or a little bit wage per day.

From the above analysis, rural India is facing many problems like irrigation, roads, infrastructure, electricity, etc. All these problems effect adversely on the Indian economy. Mainly these are the causes of poverty, unemployment, etc. To eradicate these problems the Centre and the State Governments are implementing different programs for rural development. The following analysis concentrates on various rural development programs.

\section{Dalit Women in India}

Dalit women are one of the largest socially segregated groups anywhere in the world, and make up 20 percent of the total population. Dalit women are discriminated against three times over they are poor, they are women and they are Dalits. Dalit women constitute 16.3 percent of the total female population in India. The traditional taboos are the same for Dalit men and women. Dalit women are discriminated against not only by the people of higher casts but also within their own community. Men are dominating in dalit communities.

The situation of dalit women in India is unexplainable. They are one among the worst suffers from socio-cultural, political and economic exploitable in India, oppression, and violence. Their worries are boundless. They are the ones who form real teeming millions in India and are affected by all kinds of social and economic oppression.

\section{Demographic Features of Dalits in Andhra Pradesh}

From the Table-2, the total population of Andhra Pradesh in 1961 Census was 359.83 lakhs of which 49.74 lakhs (13.8\%) were Scheduled Castes. It was 762.10 lakhs in 2001 Census of which 123.39 lakhs (16.2\%) Scheduled Castes. It is noticed from the data that the percent of Scheduled Caste population has been increasing from 13.8 percent to 16.2 percent. Hence, the role of Scheduled Castes in the development of Andhra Pradesh economy is increasing.

Narasimhulu, T. (2019). Impact of mgnregs on dalit women: A case study of nagari mandal in chittoor district. International Research Journal of Engineering, IT \& Scientific Research, 5(3), 14-27. 
Table 1

SC Population in Andhra Pradesh (In lakhs)

\begin{tabular}{cccc}
\hline Census year & $\begin{array}{c}\text { Total } \\
\text { population }\end{array}$ & $\begin{array}{c}\text { Total SC } \\
\text { population }\end{array}$ & $\begin{array}{c}\text { \% SC population in total } \\
\text { population }\end{array}$ \\
\hline 1961 & 359.83 & 49.74 & 13.8 \\
1971 & 435.03 & 57.75 & 13.3 \\
1981 & 535.50 & 79.62 & 14.9 \\
1991 & 665.08 & 105.92 & 15.9 \\
2001 & 762.10 & 12.39 & 16.2 \\
\hline
\end{tabular}

\section{Demographic Features of Dalit Women in India}

Today, the percentage of dalit population in India has substantially increased. According to the Census Report of 2001, they formed nearly 16.5 pre cent are slightly more than 169 million population in India. One out of the every 6 Indians belongs to dalit community. The highest number of dalits are found in Uttar Pradesh (21\%) followed by West Bengal (12\%), Bihar (9\%), Tamilnadu (8\%) and Rajasthan (5.5\%) and so on. The following detail gives some information on the demographic features of dalit women. All are shown in the Table-1.

As per the Census 2001, the total population of India was 1028.6 millions of which 166.6 million are dalits. Out of this 80.5 million were dalit women. The population of India has risen to 1210.6 million in 2011 Census. At the same time, the population of Scheduled Castes also rose to 201.3 million. It increased dalit women to 97.8 million. All these are shown in the following Table-1.

Table 2

SC Women Population in India

\begin{tabular}{lrr}
\hline \multicolumn{1}{c}{ Description } & $\begin{array}{c}\text { SC Population in 2001 Census } \\
\text { (in Millions) }\end{array}$ & $\begin{array}{c}\text { SC Population in 2011 Census } \\
\text { (in Millions) }\end{array}$ \\
\hline Male & & 86.1 \\
Female & 80.5 & 103.5 \\
Total & 166.6 & 97.8 \\
\hline
\end{tabular}

\section{Need for development of Dalit Women}

According to the 2011 Census, the total population of dalit women is 8,65,46,940 that is about 16 per cent of the total women's population of India. Untouchability is one of the hallmarks of the Hindu society, culture, and religion. One of the greatest crimes against humanity is the practice of untouchability. Dalits are treated as untouchables. Both Dalit women and men are victims of the practice of untouchability. They are prohibited or deprived from certain acts and practice, access to common property resources, services and entry and participation in the socio-cultural sphere at private, common and public places.

Compared to women of other categories Dalit women opportunities have relatively high social mobility. Their mobility, however, is due to their compulsion to get employment, including labor works.

Dalit women like any other Indian women, perform three roles. They are reproductive, productive and community. They spend most of their time in reproductive and domestic works. Such as giving birth to babies, childcare, cooking, washing clothes, fetching water and firewood and raising animals. They also work as a farm or agriculture laborers, daily wage workers, traditional occupational works and household productions.

In 1991, 70 percent of the total SC households were landless or near landless (owning less than one acre). This increased to 75 percent in 2000. In 1991, 13 percent of the rural SC households were landless. As per the Agriculture Census of 1995-96, the bottom of 61.6 percent of operational holdings accounts for only 17.2 percent of the total operational land area. As against this, the top 7.3 percent of operational holdings accounted for 40.1 percent of the total operational area. This gives an indication of land concentration in the hand of the few.

In 2000, about 28 percent of the SC households in rural areas had acquired some access to fixed capital assets (agricultural land and non-land assets). In 2000, 49.06 percent of the working population was agricultural laborers. This shows the preponderance of Dalits in Agricultural laborers. Between 1991 and 2001, the number of agricultural 
laborers in India increased from 7.46 crores to 10.74 crores and a large proportion of them were Dalits. The average number of working days available to an agricultural laborer slumped from 123 in 1981 to 70 in 2005.

40 percent of child labor from SC families. The per capita income of Dalits is low compared with others. It reflects on poverty. In 2000, 35.4 percent of the SC population was below the poverty line in rural areas. The largest incidence of poverty in rural areas was among agricultural laborers followed by non-agricultural laborers. The monthly per capita expenditure for all households types was lower for SCs than others.

The unemployment status is high in rural areas compared with non-SC/ST. According to the $2001 \mathrm{Census,} \mathrm{the}$ literacy rate among SCs was 54.7 percent. Among Women, the literacy for SCs was 41.9 percent because of high unemployment, poverty, and low educational status. Infant mortality, child mortality rate are high compared with non SC/STs.

While Dalit Women share common problems of gender discrimination with their high caste counterparts. They also suffer from problems specific to them. Dalit Women are the worst affected and suffer the three forms of oppression - caste, class, and gender. As some of the above figures, these relate to extremely, low literacy and education levels, heavy dependence on wage labor, discrimination in employment and wages, heavy concentration in unskilled, low paid and hazardless movement jobs, violence and sexual exploitation, being the victims of various of superstitions, etc.

Based on the above analysis almost every socio-economic indicates shows that the position of SC families, in particular, Dalit Women, is awful. In many cases, their plight is getting worse. To ensure a better life for the crores of people including Dalits in our country, the Central and State Governments taking necessary measures by implementing several rural development programs. This rural development programs directly or indirectly impact on all weaker sections including dalit women.

\section{Mahatma Gandhi National Rural Employment Guarantee Scheme (Mgnregs)}

In order to alleviate a lot of the rural problems, the Central Government, as well as State Government, operates various programs. Community Development Programme, NREP, RLEGP, IAY, IRDP, Food for Work Programme, IADP, DPAP, etc. are some among them. The Mahatma Gandhi National Rural Employment Guarantee Scheme (MGNREGS) is one among them.

The Government of India passed the National Rural Employment Guarantee Act, 2005 (Central Act No.42 of 2005). This Act gives a legal guarantee of at least one hundred days of wage employment in a financial year to a rural household, whose adult members volunteer to do unskilled and manual work. The Act is applicable in the Districts notified by the Government of India.

The primary objective of the Scheme is to provide livelihood security to the households in rural areas by providing not less than 100 (one hundred) days of guaranteed wage employment in every financial year to every household, whose adult members volunteer to do unskilled and manual work and creation of durable assets and strengthening the livelihood resource base of rural poor.

\section{Review of Literature}

Binony, N. Verma \& Madhuri Nath (2004), in their book entitled 'Women and Rural Development' explains the role of women in rural development programs. They opined that in the orientation of more systematic approach to training and employment planning for rural women is needed particularly in view of changes in pattern and process of production due to the introduction of technology at all levels.

Duncan \& Forrester (1974), in their work entitled Initial Occupational Patterns of Scheduled Caste Graduates in India studied the position SC people on the social scale index comprising items like poverty, social status, health life expectancy, literacy and education and found them at the bottom of the scale.

Similarly, Singh \& Malik (1989), in their work entitled Scheduled Caste and Development: Structure, Process and Performance found that the implementation of the scheme for SC is very poor.

Nancharaiah (1990), in his work 'The Changing Position of SCs as Agricultural Labourers in Indian Market' analyzed the economic development of the SCs since independence with reference to access to land, occupational distribution, access to education an incidence of poverty. He is of the opinion that though there is a cognizable improvement in the development of the SCs, it is however not substantials the community remained as agricultural labor.

Narasimhulu, T. (2019). Impact of mgnregs on dalit women: A case study of nagari mandal in chittoor district. International Research Journal of Engineering, IT \& Scientific Research, 5(3), 14-27. https://doi.org/10.21744/irjeis.v5n3.644 
Anil Bharadaj (2002), in his book entitled 'Welfare of Scheduled Castes in India' pointed out that the Scheduled Caste population, therefore was deprived on the benefits of development, made under both the macro and micro plants.

Parvathi Devi (2007), in her Ph.D. thesis entitled 'Empowerment of Scheduled Caste Women - A Study of Krishna District of Andhra Pradesh' discussed demographic and amenities available, socio-economic conditions of Scheduled Caste women in Krishna District of Andhra Pradesh. She concluded the thesis by saying that Scheduled Castes a large number of Scheduled Women are landless agricultural laborers working for others as daily wages.

Jagan Karade (2008), in his article 'Development of Scheduled Castes and Scheduled Tribes in India' says that the backwardness of SCs will be evident from their unemployment, dependence on agriculture, illiteracy and social segregation. In terms of residence, housing and health conditions, the condition of the SCs are precarious. Even now in many villages, they have to suffer residential segregation and direct and indirect social boycott. There are many among them who are too poor to build their houses. On account of their poverty and unhygienic living conditions, they, in large numbers, suffer from malnutrition, physical disabilities, and diseases such as tuberculosis, leprosy, malaria, and general diseases.

Anil Kumar Thakur \& Thakur R.N.(2008), in their book 'Impact of Economic Reform Policies on Dalit and Weaker Section' (ed), narrates that as per as economic reforms and Dalits are concerned it would be too simplistic and populist to say that nothing has changed in the last fifty years.

Darsha Singh (2009), in his article entitled 'Development of Scheduled Castes in India - A Review' gives a statement that the economic growth with social justice has been the major objective of the planning process and rural development programs in India. The government would not only take into account economic goals but also consider social aspects like providing access to deprived sections to participate in the development process.

\section{Significance of the Study}

The empowerment of rural Dalit women is crucial for the development of rural India. Bringing rural Dalit women in the mainstream of development, the ministry of rural development has been introducing various rural development programs. They include SGSY, JGSY, IAY, DWACRA, IRDP, JRY, MGNREGS, etc. The government of Andhra Pradesh state has also implemented various programs to the upliftment of rural Dalit Women. They include DEEPAM, INDIRAMMA, etc. All the programs will affect directly or indirectly the rural Dalit Women. The project report is to study these impacts.

Objectives of The Study

The main objective of the study is to analyze the impact of Mahatma Gandhi National Rural Employment Guarantee Scheme on dalit women in Andhra Pradesh state. The following are some other objectives of the study.

1) To study the participation of dalit women in MGNREGS in Andhra Pradesh.

2) To examine the employment and assets generation through MGNREGS especially to dalit women.

3) To study the awareness of MGNREGS among dalit women.

4) To analyze the opinions of dalit women on MGNREGS in rural areas.

To suggest suitable measures for better implementation of MGNREGS as well as other rural development programs for all-round development of dalit women.

\section{Materials and Methods}

In the light of the above objectives, 10 villages of the Nagari Mandal were selected by loose random sample technique. A total of 272 households have been selected with an average of 25 families from each village who have been selected randomly while visiting the villages. Statistical data has been collected through primary and secondary sources. For collecting the primary data, two types of questionnaires were canvassed, one for a profile of the village and the second for the impact of rural development programs on dalit women. In order to evaluate the data simple statistical tools such as percentages are used the opinions of rural dalit women were summarized in marginal tables. 


\section{Results and Discussions}

\section{Impact of Mgnregs on Dalit Women}

The Government of India, as well as Government of Andhra Pradesh, has been implementing various rural development programs for the upliftment of weaker sections. The MGNREGS is one among them. The following analysis shows the impact of MGNREGS on Dalit women in Andhra Pradesh.

\section{Awareness of APNREGS}

Table 3 shows that out of the 250 respondents $54.4 \%$ are aware of the MGNREGS and $45.6 \%$ are unaware of the scheme. The following tables analyze the cross-tabulation of awareness of MGNREGS on region and district of the respondent.

Table 3

Awareness of MGNREGS Scheme

\begin{tabular}{clrr}
\hline Sl. No. & \multicolumn{1}{c}{ Did you know MGNREGS scheme? } & Frequency & Percent \\
\hline 1. & Yes & 148 & 54.4 \\
2. & No & 124 & 45.6 \\
& Total & 272 & 100.0 \\
\hline
\end{tabular}

\section{Creation of Employment or Benefits under the MGNREGS}

'Did you get employment under MGNREGS' was posed to the respondents to examine the creation of employment under MGNREGS in the sample area Table 4 shows $38.4 \%$ of respondents got employment under MGNREGS while $61.6 \%$ of respondents did not get in any employment under this scheme.

Table 4

Creation of Employment or Benefits under the MGNREGS

\begin{tabular}{|c|c|c|c|}
\hline Sl. No. & Have you benefited from MGNREGS scheme? & Frequency & Percent \\
\hline 1. & Yes & 104 & 38.4 \\
\hline 2. & No & 168 & 61.6 \\
\hline & Total & 272 & 100.0 \\
\hline
\end{tabular}

\section{Creation of Number of Working Days under MGNREGS}

Creation of the number of working days under MGNREGS is divided into 5 categories. They are below 14 days, 15-50 days, 51-75 days, 76-100 days and 101 and above days. From the Table-3 out of the 105 respondents who got employment in 2011 under the scheme, 8 respondents got 14 working days, 55 respondents got 15-50 working days, 21 respondents got 51-75 working days, 19 respondents got 76-100 working days and 2 respondents got 101 and above working days.

Table 5

Creation of Number of Working Days under MGNREGS

\begin{tabular}{clcc}
\hline S1. No. & \multicolumn{1}{c}{$\begin{array}{l}\text { If you got employment under the MGNREGS how } \\
\text { many days you got employment under the scheme? }\end{array}$} & \multirow{2}{*}{ Frequency } & Percent \\
\hline 1. & 14 days & 5 & 3.1 \\
2. & $15-50$ days & 21 & 20.2 \\
3. & $51-75$ days & 19 & 7.6 \\
4. & 76 - 100 days & 7.0 \\
\hline
\end{tabular}

Narasimhulu, T. (2019). Impact of mgnregs on dalit women: A case study of nagari mandal in chittoor district. International Research Journal of Engineering, IT \& Scientific Research, 5(3), 14-27. https://doi.org/10.21744/irjeis.v5n3.644 


\begin{tabular}{|c|c|c|c|}
\hline 5. & 101 and above days & 2 & .6 \\
\hline \multirow[t]{2}{*}{6.} & Not Applicable & 167 & 61.6 \\
\hline & Total & 272 & 100.0 \\
\hline
\end{tabular}

Request the Grama Panchayathi to Provide Employment under the MGNREGS

Table-4 shows that out of the 272 sample dalit women, 102 dalit women requested the Grama Panchayathi to provide employment under MGNREGS, 3 Dalit women did not request and the question is not applicable to 167 Dalit women.

Table 6

Request the Grama Panchayathi to Provide Employment under the MGNREGS

\begin{tabular}{clcc}
\hline S1. No. & $\begin{array}{r}\text { Did you request the Grama Panchayathi to provide } \\
\text { your employment under MGNREGS? }\end{array}$ & Frequency & Percent \\
\hline 1. & Yes & 102 & 37.3 \\
2. & No & 3 & 1.2 \\
3. & Not Applicable & 167 & 61.6 \\
& Total & 272 & 100.0 \\
\hline
\end{tabular}

\section{Issue of Job Cards}

Two questions were posed to the respondents to analyze the issue of job cards. The first question is 'Did the Grama Panchayathi issue the job cards to you?' and the second question is 'if issued, for how many days the job cards were issued by the Grama Panchayathi?' With regard to the first question, the Table 7 shows that 101 respondents said that job cards were issued and 7 respondents said that job cards were not issued the Grama Panchayathi.

Table 7

Issue of Job Cards

\begin{tabular}{clcc}
\hline Sl. No. & Is the Grama Panchayathi issued job cards to you? & Frequency & Percent \\
\hline 1. & Issued & 101 & 37.1 \\
2. & Not issued & 7 & 2.4 \\
3. & Not Applicable & 164 & 60.5 \\
& Total & 272 & 100.0 \\
\hline
\end{tabular}

\section{Information on Availability of Time and Days}

With regard to the question 'Did you inform the Grama Panchayaths in written about the availability of time and days after job cards had been taken' is analyzed in the Table 8 . It is evident from the table that 97respondents were informed and 8 respondents were not informed in writing about the availability of time and days after job cards were taken.

Table 8

Information on Availability of Time and Days

\begin{tabular}{|c|c|c|c|}
\hline Sl. No. & $\begin{array}{l}\text { Did you inform the Grama Panchayathi in written about the } \\
\text { availability of time and days after job cards had been taken? }\end{array}$ & Frequency & Percent \\
\hline 1. & Informed & 97 & 35.5 \\
\hline 2. & Not informed & 8 & 2.9 \\
\hline \multirow[t]{2}{*}{3.} & Not Applicable & 167 & 61.6 \\
\hline & Total & 272 & 100.0 \\
\hline
\end{tabular}




\section{Employment Provided Under the APNREGS}

With regard to employment provided under MGNREGS, the Table 9 shows that 61 respondents said that the Grama Panchayathi provided employment under MGNREGS after written request within 15 days and 38 respondents said 'not provided'.

'If employment is not provided Grama Panchayathi, have you been paid unemployment pension' is another question and replies of sample Dalit Women are consolidated in Table 10. It is evident from the table that out of the 44 beneficiaries 3 respondents said 'paid' and 41 respondents said 'not paid'. It is to be noticed from the table there are 41 respondents who said not paid means the MGNREGS officials are failed in paying unemployment pension.

Table 9

Provided Employment under the MGNREGS

\begin{tabular}{|c|c|c|c|}
\hline Sl. No. & $\begin{array}{l}\text { Is the Grama Panchayathi provided employment under } \\
\text { MGNREGS after your written request within } 15 \text { days? }\end{array}$ & Frequency & Percent \\
\hline 1. & Provided & 61 & 22.3 \\
\hline 2. & Not provided & 38 & 14.1 \\
\hline \multirow[t]{2}{*}{3.} & Not applicable & 173 & 61.6 \\
\hline & Total & 272 & 100.0 \\
\hline
\end{tabular}

Table 10

Payment of Unemployment Pension

\begin{tabular}{|c|c|c|c|}
\hline Sl. No. & $\begin{array}{l}\text { If it is not provided, have you been paid unemployment } \\
\text { pension? }\end{array}$ & Frequency & Percent \\
\hline 1. & Paid & 3 & 1.0 \\
\hline 2. & Not Paid & 41 & 15.1 \\
\hline \multirow[t]{2}{*}{3.} & Not applicable & 228 & 83.9 \\
\hline & Total & 272 & 100.0 \\
\hline
\end{tabular}

\section{Payment of Wages}

Two questions, like 'How much wage is paid per day in working days?' and 'Do they pay equally to both men and Women' were asked to study payment of wages to Dalit Women under MGNREGS. With regard to the first question 33 respondents get below Rs.60/-, 60 respondents get Rs.60-120 and 12 respondents Rs.122 and above as wage per day in working days according to the Table 11.

Table 11

Payment of wages

\begin{tabular}{|c|c|c|c|}
\hline Sl. No. & How much wage is paid per day in working days (In Rs.) & Frequency & Percent \\
\hline 1. & Below 60/- & 33 & 12.0 \\
\hline 2. & $61-120$ & 60 & 22.1 \\
\hline 3. & 122 and above & 12 & 4.3 \\
\hline 4. & Not applicable & 167 & 61.6 \\
\hline & Total & 272 & 100.0 \\
\hline
\end{tabular}

\section{Equal Payments to Both Men and Women}

With regard to equal payment of wages to both men and women, the Table 12 shows that 22 beneficiaries of MGNREGS got equal wages along with men.

Narasimhulu, T. (2019). Impact of mgnregs on dalit women: A case study of nagari mandal in chittoor district. International Research Journal of Engineering, IT \& Scientific Research, 5(3), 14-27. 
Table 12

Equal payments to both men and women

\begin{tabular}{|c|c|c|c|}
\hline Sl. No. & Do they pay equally to both men and women? & Frequency & Percent \\
\hline 1. & Yes & 22 & 8.0 \\
\hline 2. & No & 82 & 30.2 \\
\hline 3. & Not applicable & 168 & 61.8 \\
\hline 4. & Unknown & 0 & - \\
\hline & Total & 212 & 100.0 \\
\hline
\end{tabular}

Time Taking for Payment of Wages under the MGNREGS

The response on the question 'How many days did they take for payment of wages under MGNREGS?' is analyzed in the Table-11. Based on the table, 31 respondents out of the 104 beneficiaries said 'below 7 days', 48 respondents said '7-14 days' and 25 respondents said 'After 14 days'.

Table 13

Time taking for payment of wages under the MGNREGS

\begin{tabular}{|c|c|c|c|}
\hline Sl. No. & $\begin{array}{l}\text { How many days did they take for payment of } \\
\text { wages under the MGNREGS? }\end{array}$ & Frequency & Percent \\
\hline 1. & Below 7 days & 31 & 11.5 \\
\hline 2. & 7-14 days & 48 & 17.7 \\
\hline 3. & After 14 days & 25 & 9.3 \\
\hline 4. & Not applicable & 168 & 61.6 \\
\hline & Total & 272 & 100.0 \\
\hline
\end{tabular}

Wages Paid under the MGNREGS

With regard to the question 'How much wage did you get under the MGNREGS?', the Table 14 explains that 57 respondents got below Rs.5000, 18 respondents got Rs.5000-10000 and no respondent got Rs.10000 and above wage under the MGNREGS out of the 75 beneficiaries. The remaining respondents (30) said that they are unknown of wages.

Table 14

Wages paid under the MGNREGS

\begin{tabular}{|c|c|c|c|}
\hline Sl. No. & How much wage did you get under the MGNREGS? (In Rs.) & Frequency & Percent \\
\hline 1. & Below 5000/- & 57 & 20.8 \\
\hline 2. & $5001-10,000$ & 18 & 6.8 \\
\hline 3. & 10,001 and above & 0 & - \\
\hline 4. & Unknown & 30 & 10.9 \\
\hline 5. & Not applicable & 167 & 61.8 \\
\hline & Total & 272 & 100.0 \\
\hline
\end{tabular}

\section{Mode of Spent the Wages which was got through the MGNREGS}

The Table-13 shows out of the 105 beneficiaries of MGNREGS, 66 respondents spent the wages which they got through the MGNREGS on house needs, 21 respondents to pay off their old debts, 8 respondents spent on children education, 3 respondents spent on health, no respondent save the wages, 2 respondents spent on creation of employment and 5 respondents spent on other needs. 
Table 15

Mode of spent the wages which were got through the MGNREGS

\begin{tabular}{clcc}
\hline Sl. No. & How do you spend the wage which is got through the & Frequency & Percent \\
\hline 1. & MGNREGS? & 66 & 24.3 \\
2. & For house needs & 21 & 7.6 \\
3. & Fo clear old debts & 8 & 2.9 \\
4. & For health & 3 & 1.0 \\
5. & On savings & 0 & - \\
6. & For creation of employment & 2 & .8 \\
7. & For other needs & 5 & 1.7 \\
8. & Not applicable $\quad$ Total & 167 & 61.6 \\
& & 272 & 100.0 \\
\hline
\end{tabular}

Time of Employment Created under the MGNREGS

A question 'In what time the employment is created under MGNREGS' is posed to the respondents and replies are shown in the Table-14. It may be observed from the table that out of the 104 beneficiaries of MGNREGS 5 respondents said that the employment was created under MGNREGS at the availability of agriculture and other works and 99 respondents said that the employment was created at non-availability of agriculture and other works.

Table 16

Time of Employment Created under the MGNREGS

\begin{tabular}{|c|c|c|c|}
\hline S1. No. & $\begin{array}{c}\text { In what time the employment is created under } \\
\text { MGNREGS? }\end{array}$ & Frequency & Percent \\
\hline 1. & Availability of agriculture and other works & 5 & 1.9 \\
\hline 2. & Non-availability of agriculture and other works & 99 & 36.5 \\
\hline 3. & Not applicable & 168 & 61.6 \\
\hline & Total & 272 & 100.0 \\
\hline
\end{tabular}

Types of Works the Employment Provided under the MGNREGS

Table-15 explains that out of 102 beneficiaries of MGNREGS 11 respondents said that employment is provided in water irrigation works and water harvesting works, 18 respondents said that employment is provided in afforestation and tree plantation, 30 respondents said that employment is provided in clear irrigation canals, 3 respondents said that employment is provided in the development of lands owned by SC/STs, 10 respondents said that employment is created in the development of lands of beneficiaries of land reforms, 1 respondents said that employment is provided in the development of lands owned by Below Poverty Line people, 18 respondents said that employment is provided in road works and 3 respondents said that employment is provided in other works under the MGNREGS.

Table 17

Types of works the employment provided under the MGNREGS

\begin{tabular}{clcc}
\hline Sl. No. & In which types of work, the employee is provided under \\
this scheme? & Frequency & Percent \\
\hline 1. & Water irrigation works and water harvesting & 11 & 3.7 \\
2. & Afforestation and tree plantation & 18 & 6.8 \\
3. & Clear out irrigation canals & 30 & 10.9 \\
4. & Development of lands owned by SC/STs & 10 & 1.2 \\
5. & Development of lands of beneficiaries of land reforms & 1 & 3.5 \\
6. & Development of lands of beneficiaries of IAY program & .4 \\
\hline
\end{tabular}

Narasimhulu, T. (2019). Impact of mgnregs on dalit women: A case study of nagari mandal in chittoor district. International Research Journal of Engineering, IT \& Scientific Research, 5(3), 14-27. https://doi.org/10.21744/irjeis.v5n3.644 


\begin{tabular}{clcc}
\hline 7. & Construction of Social assets & 8 & 3.1 \\
8. & Road works & 18 & 6.6 \\
9. & Other works & 3 & 1.0 \\
10. & Not applicable & 170 & 62.9 \\
& Total & 272 & 100.0 \\
\hline
\end{tabular}

Mode of Payment of wages under MGNREGS

While answering the question 'What is the mode of payment of wages under the MGNREGS?', from the Table16, 36 respondents told 'through banks', 55 respondents told 'through post offices' and 14 respondents told 'in cash'.

Table 18

Mode of payment of wages under the MGNREGS

\begin{tabular}{clcc}
\hline Sl. No. & \multicolumn{1}{c}{ What is the mode of payment of wages under the } \\
MGNREGS? & Frequency & Percent \\
\hline 1. & Through banks & 36 & 13.2 \\
2. & Through post office & 55 & 20.2 \\
3. & In cash & 14 & 5.0 \\
4. & Not applicable & 167 & 61.6 \\
& Total & 272 & 100.0 \\
\hline
\end{tabular}

\section{Problems in Getting Employment under the MGNREGS}

With regard to the question 'Are you facing any problems in getting employment under the MGNREGS' the frequencies in the Table 19 shows that 77respondents said 'yes' and 27 respondents said 'no' while answering the question.

Table 19

Problems in Getting Employment under the MGNREGS

\begin{tabular}{|c|c|c|c|}
\hline S1. No. & $\begin{array}{l}\text { Are you facing any problems in getting employment } \\
\text { under the MGNREGS? }\end{array}$ & Frequency & Percent \\
\hline 1. & Yes & 77 & 28.3 \\
\hline 2. & No & 27 & 10.1 \\
\hline \multirow[t]{2}{*}{3.} & Not Applicable & 168 & 61.6 \\
\hline & Total & 272 & 100.0 \\
\hline
\end{tabular}

\section{Types of Problems in Getting Employment under the MGNREGS}

To the study the problems that are faced by the respondents in getting the employment under the MGNREGS, a question 'if yes, what type of problems are you facing' was posted. It is being observed from the Table 20 that 14 respondents are facing the problems at the time of applying for job cards, 10 respondents are facing problems at the time issuing job cards, 6 respondents are facing problems in information about employment, 21 respondents are facing problems in paying wages, 16 respondents are facing problems at workplace, 10 respondents are facing problems by political involvement and no respondent is facing other problems.

Table 20

Type of problems in getting employment under the MGNREGS

\begin{tabular}{clcc}
\hline S1. No. & \multicolumn{1}{c}{ If yes, what type of problems are you facing? } & Frequency & Percent \\
\hline 1. & At the time of applying for job cards & 14 & 5.2 \\
2. & In issuing job cards & 10 & 3.7 \\
3. & Not informing about employment & 6 & 2.1 \\
\hline
\end{tabular}




\begin{tabular}{llcc}
4. & In paying wages & 21 & 7.6 \\
5. & At workplace & 16 & 6.0 \\
6. & Political involvement & 10 & 3.6 \\
7. & Others & 0 & - \\
8. & Not applicable & 195 & 71.7 \\
& Total & 272 & 100.0 \\
\hline
\end{tabular}

\section{Conclusion}

1. The study observed that 54.4 per cent of dalit women are aware and 45.6 per cent of dalit women are unaware of the MGNRGS. Hence, it is suggested that wide publicity should be given to MGNREGS in all regions and districts.

2. It is observed from the study that around 40 per cent of dalit women are participating and benefiting under the MGNREGS. It means most of the dalit women have not participated and benefited under the MGNREGS. Hence, it is suggested that initiative steps should be made to motivate dalit women to participate in the MGNREGS.

3. The study found that most of the dalit women beneficiaries got employment in between 15-50 working days. As per the norms of the MGNREGS scheme 100 days of employment will be provided to a person in a family. But the MGNREGS scheme has failed to provide 100 days of employment. It is also opined that income from below 50 working days is not sufficient for survival of dalit women. Hence, it is suggested that the government should provide employment throughout the year.

4. Data on creation of employment shows that 38.4 per cent of sample dalit women did get employment under the MGNREGS. It is also concluded that the MGNREGS is not creating employment for all dalit women. Hence, it is suggested to provide employment to all dalit women.

5. It is observed from the study that the Grama Panchayathis are not providing employment to all employment job card holders. Hence, it is suggested that the government should provide employment to all job card holders.

6. It is concluded from the data that most of the beneficiaries of MGNREGS got employment at the time of non-availability of agriculture or other works. It is also concluded that the MGNREGS got success in this context.

7. It is concluded from the study that most of the dalit women were employed in clearing irrigation canals under the MGNREGS. Hence, it is suggested that the authorities concerned should provide employment in common places of the village like construction of schools, community buildings, parks etc.

8. The study found that dalit women are facing discrimination in payment of wages. They are not equally paid to both men and women. Hence, it is suggested that the government should take necessary steps to equal wages to both men and women.

9. The study found that income generation under the MGNREGS was meager. This is due to low wage rate. Hence, it is suggested that wage rate should be hike from Rs.121 to Rs.200 per day as inflation rate has goes up. Also suggested to link this with market wage rate and make changes accordingly.

10. It is found that most of the dalit women faced problems in getting employment under the MGNREGS. There are problems at the time of applying job cards, at the time of issuing job cards, problems in informing about employment, problems in payment of wages, political involvement etc. Hence, it is suggested that online facility should be arranged to apply and issue of job cards.

\section{Conflict of interest statement and funding sources}

The author declared that he has no competing interest. The study was financed by independent funding.

Statement of authorship

The author has a responsibility for the conception and design of the study. The author has approved the final article.

\section{Acknowledgments}

The author would like to thank the editor of IRJEIS for their valuable time, support, and advice in completing the current study.

Narasimhulu, T. (2019). Impact of mgnregs on dalit women: A case study of nagari mandal in chittoor district. International Research Journal of Engineering, IT \& Scientific Research, 5(3), 14-27. 


\section{References}

Bhardwaj, A. (2002). Welfare of Scheduled Castes in India: Gandhi's Social Approach: Ambedkar's Political Approach, Constitutional Safeguards, Schemes for Welfare of Scheduled Castes. Deep and Deep Publications.

Darshan, S. (2009). Development of scheduled castes in India-a review. Journal of Rural Development (Hyderabad), 28(4), 529-542.

Devi, P. P. (2010). Empowerment of rural scheduled caste women: a study of Krishna district, Andhra Pradesh.

Duncan, B. F. (1974). 'Initial Occupational Patterns of Scheduled Caste Graduates in India'. New Frontiers in Education, 4.

Education, D. (2002). G. Nancharaiah. Education and the Disprivileged: Nineteenth and Twentieth Century India, 163.

Karade, J. (Ed.). (2009). Development of scheduled castes and scheduled tribes in India. Cambridge Scholars Publishing.

Kustina, K. T., Dewi, I. G. A. A. O., Prena, G. D., \& Utari, I. G. A. D. (2018). MSMEs credit distribution and nonperforming loan towards banking companies profit in Indonesia. International Journal of Social Sciences and Humanities, 2(1), 10-23. https://doi.org/10.29332/ijssh.v2n1.72

Pandey, M. (2017). Impact of goods and service tax (GST) on Indian tax structure. International Research Journal of Management, IT and Social Sciences, 4(3), 22-33.

Singh, H., \& Malik, A. (1989). Scheduled Caste and Development: Structure, Process and Performance. $K U$ Research Journal, Kurukshetra University, 33.

Thakur, A. K., \& Padmadeo, K. B. (Eds.). (2008). Growth and Diversification of Agriculture. Deep and Deep Publications.

Verma, B. N., \& Nath, M. (2004). Women and Rural Development Programmes. BR Publishing Corporation.

Vishwakarma, D. (2016). Swachh bharat abhiyan clean India abhiyan. International Research Journal of Management, IT and Social Sciences, 3(3), 48-52. 


\section{Biography of Author}

\begin{tabular}{||l|l||}
\hline \hline & Lecturer in Economics, Government Degree College NAGARI-517590, CHITTOOR \\
& Dist., A.P. Andhra Pradesh 517590, India \\
& Email: narasimha.tirivilli90@gmail.com \\
& \\
\hline
\end{tabular}

Narasimhulu, T. (2019). Impact of mgnregs on dalit women: A case study of nagari mandal in chittoor district. International Research Journal of Engineering, IT \& Scientific Research, 5(3), 14-27. https://doi.org/10.21744/irjeis.v5n3.644 